\title{
Specifics of Migration from Russia to Europe in the Course of Crisis: The Flight of the Creative Class
}

\author{
Prof. L. Bronzino \\ Peoples' Friendship University of Russia, Sociology Chair \\ Ibronzino@gmail.com
}

Doi:10.5901/mjss.2015.v6n1s1p200

\begin{abstract}
Russian emigration has its own specifics related to the fact that for the general population a "crisis" is a part of a purely European phenomenon. The poorest part of the society is sure that Europe (European values related to human rights, market economy and liberal democracy) is failing, and this is manifested by the "crisis". So for traditionally the most vulnerable and marginalized populations, migration seems pointless. However, the statistical analysis suggests that migration to Europe from Russia is well gathered after the presidential election. It is specifically predominant amongst the middle class. Russian migrants in Europe tend to already have higher education, higher-paying jobs, own their own homes and are used to quite a high level of material and cultural consumption. All of this the migrant is ready to leave for the sake of (sometimes illusory) prospects in Europe. Thus, the desire to leave Russia is expressed, and, increasingly, is undertaken by those who are the backbone of the Russian society. These are people who are sufficiently secure at home and their desire to emigrate is not related to any kind of financial distress. As it is shown in the quantitative analysis carried out by us, current migration is related to political reasons the lack of the freedom of speech and the overall inability to influence the political destiny of the country. This general conclusion was made based on extensive research which sought to determine the nature of the Russian migration to Europe. It is defined as representing a kind of "new wave of dissent", caused primarily not due to economic distress, but rather, because of the political futility of the regime in the eyes of the middle class.
\end{abstract}

Keywords: Russia; migration; middle class; creative class; social protests; quantitative analysis; protest moods.

\section{Introduction}

The rise of migration is one of the most acute problem and worrisome aspects of the financial crisis. The Russian migration has its own specific features, as the majority of people considers crisis a purely European phenomenon, which influences Russia only indirectly. Due to propaganda activities of the Russian government via mass media the poorest groups of the population believe that Europe (European values related to human rights, market economy and liberal democracy and politics) is collapsing, and this is manifested by the "crisis". On the one hand, the existence of the economic crisis in Russia has never been admitted by the government that acts as some sort of "consoler" or "rescuer" from the disasters, which Europe experiences today. This predetermines the dominating in media discourse of crisis, which reflects the crisis conscience, concept interpreting typical for Russia and Europe phenomenon of the steady rise in public pessimistic sentiments. They predetermine different social practices (slower consumer activity, political inactivity, radicalization of electoral behaviour, transformation of family roles, shifts in career and education and the other phenomena, generated by the crisis conscience, which, in turn, can be a product of all of them). Under such circumstances, those classes of population which are traditionally more affected by the consequences of crisis (e.g. increase in unemployment, weak social protection and stronger censorship in mass media space in order to ease protest moods) do not consider emigration to more economically developed countries.

The increased migration has become one of the main themes in the Russian opposition media (it was discussed mainly in the web) following the presidential elections and public protests in 2011-2012. The majority of messages were focused on brain drain: the Russian creative class started to consider the opportunity of emigrating to another country having disappointed with the current state of affairs in the country, having realized that their views are not taken into consideration, and having concluded that there will be no changes for the best over the next 12 years, two tentative terms of Putin's presidency, which he hopes to run amid the current situation in the country and the public opinion.

The reasons behind the current state of affairs are well defined by D. Oreshkin (D. Oreshkin, 2011), who described it as "the sixth wave of emigration" attributing it not to the economic problems of the most educated, employed, and financially secured part of the population but to the infeasibility of personal fulfillment within the country, where there is a 
lack of freedom. In the largest Russia's social networks the increasingly high number of communities under the name of "It's time to leave!" emerge. The topic is widely discussed, yet, from the scientific point of view, it has much controversy.

The objective of the paper is to analyze the specific features of Russian migration, increased in time of crisis. The hypothesis of the article is that the increased migration was not driven solely by the economic conditions, but it is predetermined by political ambiance, felt by Russian creative class. Theoretical frame of R. Floridas' concept of "creative class" make possible to prove, that most of those who leave Russia today belong to creative class, and their flight is a type of protest against contemporary Putins' policy.

\section{Specifics of Understanding the Creative Class in Russia}

Let us start explaining its controversial characteristics with the issue of attributing the term "creative class" to that part of Russia's population who considers the possibility to emigrate. The term itself defined by R. Florida (R. Florida, 2002) is rather vague as it reflects the characteristics which can hardly be registered by statistics or quantitative sociological methods. It is impossible to measure its real scale: on the one hand, the representatives of the creative class are the carriers of the creative conscience; on the other hand, they can have non-creative occupation; or vice versa, they can belong to innovative professional groups although without having explicitly creative conscience, which, according to Florida, should make them a driver of social development. Florida prefers more accurate definition while in Russia the definition with additional context has become popular. It underlines that this social group includes not only all the people with a postgraduate degree and prestigious job but those, who have peculiar creative potential and ability to generate new ideas. Meanwhile, a narrow explanation of the creative class does not prevent the Russian researchers from considering it as a potential source of social development. This transition in Russian research discourse can be explained by very popular idea of its specifics in Russia, which makes the Russians exceptional carriers of creative power and differentiates them from pragmatically oriented western people. Utilitarianism of the West is opposed to creative spirituality of the Russians. This leads to two conclusions (both of them bode well with anti-western official Putin's discourse): first, western liberal values from free market to developed democracy are alien to the Russians; second, the Russian nation has some internal power, which allows people to develop in a specific way with no need for external prowestern sources, no matter whether it is western understanding of democracy and human rights or the idea of integration with global community.

The creative class, interpreted like the stated above, reflected not only in scientific papers, but in Russia's Economic Development Strategy until 2020 as well [Ministry of Economic Development of the Russian Federation].

However, the officially announced importance of the creative class, related to the potential development both in official documents and in public conscience, does not match the assessment of innovativeness and creative abilities as its core qualities. Innovativeness should comply with the official ideology and its key purpose should be to encourage that very development, which is chosen by the Russian government. The Russian creative class does not have any right either to interfere in the development strategy or to express the view on the events, which take place in the country, if it does not comply with that of the government. The government therefore is ready to rely on the creative class only when the latter agrees with the former, in other cases the creative class is viewed as a hazard.

At the same time, it is innovativeness that makes the creative class that very social group, where social protests and opposition to the official ideology can arise. As we speak about the intellectual minority, which under the current circumstances managed to accumulate cultural capital and to achieve the solid social and creative position in the postSoviet time, while nowadays it claims for the feasible citizen rights and freedom. In reality, the government requires from the creative class to demonstrate limited creativity, which is focused on creative work, which the Russian government needs.

Under such circumstances, the Russian creative class cannot be quantitatively estimated. If we base on the number of characteristics, proposed by Florida, we can estimate it (the Russian creative class should include all the people, whose professional occupation is related to intellectual activity and therefore has indisputable creative nature). There are some objective indicators with regard to people who have a postgraduate degree, so we can assume that it is them who constitute the basis of the creative class. According to the Russian Public Opinion Research Center (VCIOM), nearly a quarter of the Russians form the basis. At the same time, $45 \%$ of the Russians say that their job fully complies with their education, i.e. although the majority of the Russians do not work in the specialty, nevertheless from their subjective points of view, their professional competency is enough for the occupied positions, and the obtained education provided them with all the skills for professional activity [Rosstat. Nearly a Quarter of the Russians Have a Graduate Degree].

According to the widely spread in the Russian academic and publicistic literature interpretation (A. Okara, 2009), 
the Russian creative class cannot be measured in quantitative terms, though there are some endeavours to do it. A. Okara, who writes about homo creativus and considers the creative class a psychological type that is similar in its innovative potential and role in economy to the entrepreneurs, described by J. Schumpeter (J. Schumpeter, 2007), says that about $10-20 \%$ of the Russian population belongs to the creative class while mentioning that its social and anthropomorphous features are at odds with the Russian authoritative government.

However, it is a rough quantitative estimation, which is likely based on the existing estimations of the middle class. The use of this term with regard to modern Russia also casts a lot of doubt of a methodological and social kind. Firstly, despite the huge amount of research [Gorshkov M., Golenkova Z., Tikhonova N. (2006) The City Middle Class in Presentday Russia. The Research Report. The Institute of Sociology of the Russian Academy of Sciences], national scientists have not managed to list all the typical features of the middle class. Secondly, it is due to the fact that middle class is often regarded not only as the people bearing certain social features, but as the majority of population with the leading position in social hierarchy. The average standard of life in Russia is quite low - (the average income stood at about RUB 22,717 per month, or $€ 567$ [The data on employers' monthly income]. An average Russian therefore does not belong to the middle class under the standards in contemporary foreign sociology, as only 4-6\% of the Russians match the definition. Based on the research of the middle class, B. Dubinin states: "Our respondents are not the majority in any respect, not proactive, and more importantly, they do not feel themselves being a consolidated group, which is united by common interests and values and capable of defending them" (B. Dubinin, 2012). There are the other findings in the official state discourse: in order to show the effectiveness of the officials' efforts, it is necessary to demonstrate steady growth of the middle class, as well as its well-being. According to VCIOM, the middle class, representatives of which can easily buy durable goods, but for whom it is difficult to buy really expensive things (e.g., a car), accounted for $7 \%$ of the population, as of May, 1998; in 1999-2000 only 4\% of respondents considered themselves the middle class. The figure was constantly increasing over the next few reaching 16\% in 2008 (VCIOM, 2008). Notably, VCIOM defines the middle class based on the only indicator - purchasing power - and includes all those, who have troubles with buying expensive goods, i.e. it moves upwards the range for the middle class.

The definition of the middle class therefore either seems to be vague, or it is scarce that even more complicates the interpretation of the creative class based on the middle class. The creative class in Russia is likely to account for 4$6 \%$, as Dubinin mentioned. However, according his estimates, among those the minority can be regarded as the carriers of the exceptional psychological type, which fosters the innovative conscience. Consequently, an estimation of the creative class in Russia should be based on an assumption of its absolutely scarce definition and only relative correspondence to the criteria in the Russian literature, as well as those, proposed by Florida.

\section{Migration from Russia to the European Countries and the USA}

\subsection{Overview Migration Trends in Russia}

Migration in Russia as a phenomenon, which is typical for the majority of developed countries, is in line with the global trends, yet it has its specifics. Firstly, a large number of emigrants flow to Russia from less developed countries, which have historical tights with it (this alleviates the adaptation, especially linguistic one), as well as there is no visa regime for the politically friendly countries (Uzbekistan, Tajikistan, Kazakhstan, and the other FSU countries), which Russia considers its strategic partners. Though since 1990s Russia has been considered as a strategic partner of the European Union, their partnership remains ambivalent: both counterparts declare friendly intentions and announce common goals, but the implementation of the common strategies in the most important spheres, first of all security, is postponed and no concrete steps are undertaken" (T. Renard 2011).

According to IBRD, the amount of immigrants to Russia stands at $12.5 \mathrm{mln}$ people, $99.5 \%$ of which come from the FSU countries. Russia ranks second by immigrants following the US. In addition, the deconstructive policy of the Russian government led to a large amount of illegal immigrants (according to some estimates, 2.5-3.5 mln people) [The Analysis of Migration in Russia, 2006). In this respect, relatively low level of social and economic development is that what differentiates Russia significantly from the EU countries and the US, where both economic development and social protection are at a very high level. This fact makes these countries very attractive for migrants. The average income in Russia when compared to that of the EU citizens looks quite low. Consequently, Russia is attractive only for the people from the poorest countries, which are ready to take even the most low-qualified jobs, which are not popular with the Russians primarily due to their low prestige, although most of the Russians agree to receive the comparably low salary. For our analysis, it is necessary to emphasize the importance of psychological motives in the development of the Russian labour market to be described later in this paper. 
One of the specific features of the Russian labour market can be attributed to those of the majority developed countries. It is high demand on qualified employees which is partially covered by immigrants, including illegal migrants, and which cannot be covered by the Russians themselves due to the low-prestige of these jobs. At the same time, job search even for those with higher education diploma remains a difficult process (regardless of quality and education degree), especially taking into account the imbalance between their views on the profile of some jobs and the real situation on the labour market, which to a lesser degree keeps some features of the post-industrial society (here the latter term is used in its general meaning; concepts of D. Bell (Bell, 1973), P. Drucker (Drucker, 1993), and A. Toffler (Toffler, 1990) can be equally applied). This is the paradigmatic explanatory framework to clarify the existing in Russia social and economic situation, including the creative class specifics, on the one hand, and migration trends, on the other.

We can conclude that Russia is one of those countries, which accepts a lot of immigrants and this phenomenon can be explained by specific features of its labour market. The latter is influenced by the motivational structure of workers, which can be considered representatives of the creative class. In addition, we should underline the mismatch of their requirements to the quality of labour to the opportunities available on the market. In its turn, this specific feature can be explained through the concept of R. Inglehart (R. Inglehart, 2004), who demonstrated the transition of value orientations in post-industrial society from purely material to those related to self-realization and satisfaction with labour.

\subsection{Emigration to the EU Countries}

On the back of the inflows of immigrants to Russia, the amount of emigrants is insignificant. According to the Federal State Statistics Service of Russia (Rosstat), the total number of emigrants stood at 32,458 people, as of 2009 (the latest publicly available data) [The Migration by Types of Movements]

The number of people emigrating from Russia is steadily decreasing: a sharp increase in the number of emigrants who left the country was seen after the reformation period (perestroika) - it amounted to 767,740 (as of 1990). However, it was not seen over the following decade. The data in Figure 1 show the dynamics of the emigration from Russia to the other countries.

Figure 1: The emigration from Russia to the other countries in 2000-2009

\begin{tabular}{|c|c|c|c|c|c|c|c|c|c|c|}
\hline Year & 22000 & 22001 & 22002 & 22003 & 22004 & 22005 & 22006 & 22007 & 22008 & 22009 \\
\hline Number of people emigrated & 1145,720 & 2212,166 & 1106,685 & 993,018 & 779,795 & 669,798 & 554,061 & 447,013 & 339,508 & 332,458 \\
\hline
\end{tabular}

Source: Rosstat

Thus, over the recent decade the Russian migration is characterized by a steady decrease. Even though the migration has a pronounced trend, the Russian government disregards the problem, while the concerns about the mix of emigrants now and then appear in media, as well as in scientific readings - only the best part of the population, such as postgraduates, PhDs, people with high career achievements and social statuses, wealthy people and those who believe that in another country they will manage to achieve the comparable success. Even though the scope of migration is relatively small, it can be regarded as brain drain.

To verify the statement, let us draw the attention to the data provided by the OECD.

Figure 2: The Russians immigrated to other countries in 2000-2011 (thousands of people)

\begin{tabular}{|l|c|c|c|c|c|c|c|c|c|c|c|c|}
\hline Country & 2000 & 2001 & 2002 & 2003 & 2004 & 2005 & 2006 & 2007 & 2008 & 2009 & 2010 & 2011 \\
\hline Australia & 0.487 & 0.599 & 0.743 & 0.704 & 0.801 & 0.901 & 0.976 & 0.673 & 0.906 & 1,225 & 1,114 & 1,091 \\
\hline Austria & 0.917 & 0.894 & 1,848 & 3,974 & 6,843 & 4,023 & 2,463 & 2,23 & 2,958 & 2,402 & 2,197 & 2,642 \\
\hline Belgium & 0.579 & 0.645 & 0.594 & 0.61 & 0.595 & 0.647 & 0.76 & 0.783 & 0.809 & 0.81 & 0.9 & 0.97 \\
\hline Canada & 3,523 & 4,073 & 3,677 & 3,52 & 3,685 & 3,607 & 2,851 & 2,854 & 2,547 & 2,799 & 2,215 & 1,885 \\
\hline Chile & 0.033 & 0.084 & 0.04 & 0.055 & 0.024 & 0.052 & 0.064 & 0.102 & 0.11 & 0.105 & 0.117 & 0.18 \\
\hline Czech Republic & 0.4 & 0.712 & 2,437 & 1,841 & 1,972 & 3,3 & 4,675 & 6,695 & 5,763 & 4,115 & 3,681 & 2,146 \\
\hline Denmark & 0.388 & 0.448 & 0.408 & 0.338 & 0.376 & 0.374 & 0.247 & 0.339 & 0.431 & 0.4 & 0.363 & 0.388 \\
\hline Estonia &.. &.. &.. &.. & 0.233 & 0.234 & 0.346 & 0.433 & 0.435 & 0.505 & 0.356 & 0.913 \\
\hline Finland & 2,516 & 2,539 & 2,039 & 1,665 & 1,939 & 2,081 & 2,146 & 2,488 & 2,95 & 2,336 & 2,297 & 2,795 \\
\hline France & 1,158 & 1,401 & 1,913 & 2,38 & 2,922 & 3,027 & 2,499 & 2,349 & 2,999 & 2,92 & 3,159 & 3,515 \\
\hline
\end{tabular}




\begin{tabular}{|l|c|c|c|c|c|c|c|c|c|c|c|c|}
\hline Germany & 32,727 & 35,93 & 36,479 & 31,776 & 28,464 & 23,078 & 16,425 & 14,96 & 15,052 & 15,652 & 16,063 & 17,487 \\
\hline Greece &.. &.. &.. &.. &.. & 2,696 & 1,54 & 0.962 & 1,04 & 1,2 & 1,221 & 1,436 \\
\hline Hungary &.. &.. &.. &.. &.. & 2,696 & 1,54 & 0.962 & 1,04 & 1,2 & 1,221 & 1,436 \\
\hline Iceland & 0.053 & 0.049 & 0.031 & 0.03 & 0.027 & 0.04 & 0.024 & 0.043 & 0.032 & 0.019 & 0.021 & 0.025 \\
\hline Ireland &.. &.. &.. &.. &.. &.. &.. &.. &.. &.. &.. &.. \\
\hline Irael &.. &. &.. &. &.. &.. &. &.. &. &.. &.. &.. \\
\hline Italy & 2,857 & 2,291 & 2,214 & 4,028 & 3,766 & 2,798 & 2,77 & 2,897 & 3,546 & 4,005 & 5,106 & 4,269 \\
\hline Japan & 6,422 & 6,314 & 6,583 & 7,66 & 7,071 & 6,192 & 5,024 & 4,208 & 4,531 & 4,531 & 3,462 & 2,761 \\
\hline Korea & 6,492 & 6,953 & 8,138 & 9,268 & 5,549 & 4,249 & 3,742 & 3,423 & 2,587 & 2,895 & 2,601 & 2,56 \\
\hline Luxembourg & 0.135 & 0.183 & 0.188 & 0.175 & 0.112 & 0.093 & 0.127 & 0.144 & 0.096 & 0.093 & 0.101 & 0.127 \\
\hline Mexico &.. &.. &.. &.. &.. &.. &.. & 0.055 & 0.091 & 0.132 & 0.095 & 0.095 \\
\hline Netherlands &.. &.. &.. &.. &.. &.. &.. &.. &.. & 0.876 & 0.969 & 1,173 \\
\hline New Zealand & 0.402 & 0.641 & 0.451 & 0.284 & 0.238 & 0.295 & 0.294 & 0.295 & 0.336 & 0.334 & 0.337 & 0.352 \\
\hline Norway &. .875 & 0.921 & 1,351 & 1,823 & 1,697 & 1,4 & 1,075 & 1,45 & 1,157 & 0.999 & 0.934 & 1,02 \\
\hline Poland & 1,139 & 1,639 & 1,984 & 2,059 & 2,063 & 1,852 & 1,782 & 1,618 & 1,806 & 1,567 & 1,604 & 1,62 \\
\hline Portugal &.. & 5,632 & 2,006 & 0.426 & 0.527 & 0.584 & 0.395 & 0.342 & 0.218 & 0.307 & 0.117 & 0.119 \\
\hline Slovak Republic &.. &.. &.. & 0,194 & 0,203 & 0,22 & 0,342 & 0,265 & 0,318 & 0,491 & 0,505 & 0,31 \\
\hline Slovenia &.. &.. &.. &.. &.. &.. &.. & 0,121 & 0,174 & 0,126 & 0,14 & 0,273 \\
\hline Spain & 3,521 & 4,644 & 4,609 & 4,636 & 7,354 & 7,752 & 8,041 & 7,276 & 7,172 & 6,612 & 7,382 & 8,283 \\
\hline Sweden & 1,027 & 0,967 & 1,01 & 0,967 & 1,286 & 0,959 & 1,393 & 0,943 & 0,914 & 1,094 & 1,221 & 1,186 \\
\hline Switzerland &.. &.. &.. &.. &.. &.. &.. &.. &.. &.. & 1,926 & 2,048 \\
\hline Turkey &.. &.. &.. &.. &.. &.. &.. &.. &.. &.. & 1,778 &.. \\
\hline United Kingdom & 0,649 & 0,93 &.. &.. &.. &.. &.. &.. &.. &.. &.. &.. \\
\hline United States & 16,94 & 20,313 & 20,771 & 13,935 & 17,41 & 18,083 & 13,188 & 9,426 & 11,695 & 8,238 & 6,718 & 7,944 \\
\hline
\end{tabular}

Source: Database on Immigrants in OECD Countries (DIOC)

In Figure 2 the developed countries to which the Russians migrated in 2000-2011 are presented. The EU countries are in bold. From 70,047 people who left Russia, 50,948 , or $73 \%$, went to the EU.

It is difficult to analyze the specifics of the countries, which the Russians chose as a new country for living, as there is no connection between, e.g., the level of social and economic development of a country or the level of social protection and its attractiveness for migrants from Russia. The majority of emigrants went to Germany, which, above all, sees also ethnic Germans who lived in Russia. Spain ranks second, followed by Italy and France. The situation can be explained by psychological and cultural reasons rather than social and economic ones. France and Germany are traditionally perceived by the Russians as prosperous, highly developed countries (regardless of the real economic situation in the country and the problems of immigrants in each of the states). The phenomenon of Spain (since 2000 the number of immigrants has been steadily increasing there and in 2011 exceeded the number of immigrants to Italy nearly twofold) can be explained by its popularity among the Russians as a well-known touristic destination, as well as by economic problems in the country, which e.g. led to lower prices for real estate properties. The latter makes Spain attractive for investing and living. At the same time, the unemployment rate in Spain is one of the highest in the EU (about 25\%) [Employment Outlook 2013] and there are no expectations of any positive shifts. The psychological factor is viewed as defining, as the Russians feel "psychological comfort" in Spain due to which they easily adapt its the local culture and language.

Italy is likely considered to be the country with similar culture that is interpreted by the Russians in its wide sense, i.e. Italy may be one of the leaders in terms of immigration due to supposedly similar mentality and cultural standards (the ideas are sometimes inconsistent with the reality). France is perceived in a similar to the above vein. Despite the multiple transformations in both countries the Russian have felt deep respect to France since XIX century when the Russian aristocracy preferred French to Russian. The important historical fact, which psychologically impacts the immigration, is the surges of the Russians inflowing to France - from the exile of the Russian intellectuals and nobility following the Revolution of 1917 up to the emigration of the Soviet dissidents and asylees among the cultural influencers. Moreover, many of them chose France as their home country. Thus, the certain tradition in immigration preferences of the Russians is seen. The focus on cultural and historical facts is even more so warrant, taking in account a high unemployment rate in the preferred by the Russians countries (except for Germany) that is a stumbling stone for their employment, accommodation, and adaptation.

According to Rosstat, in 2012 about 7,749 people immigrated to the European countries. In absolute terms, the 
increase in immigrants in 2011-2012 was not so impressive, however, it was $11 \%$.

\section{Creative Class in the Context of the Rise of Protest Moods}

There is no publicly available data on the quality mix of emigrants leaving Russia, i.e. their level of education, social status or career achievements. However, based on some surveys, we can describe those who plan to leave the country. The surveys were carried out by Levada-Center and were propelled by the rise in protest moods and assumptions of stronger willing to emigrate, which were widely discussed in the Russian media on the back of protest actions at the end of 2011 - early 2012.

We should remind the specifics of the protest movements, as the idea that those who are willing to emigrate from Russia (primarily to the EU countries) can be referred to the creative class is based on it. The social portrait of a protester can be described on the basis of a survey among 791 people, conducted by Levada-Center, ordered by Organizing Committee of the meeting "For Fair Elections", which took place on 24th December on the Sakharov Avenue in Moscow [Survey by Levada-Center]. The survey revealed basic social characteristics of a participant in the oppositional movement, in particular demographic features: in light of its gender mix, the majority was men $(60 \%$ of men, $40 \%$ of women). Meanwhile, in general the population in Russia comprises of about $46 \%$ of men and $54 \%$ of women [The Number of Men and Women, Rosstat, 2011]. 25\% of protesters were less than 24 years, 31\% of respondents were at the age of 25-39 (thus, the majority, or 56\%, was represented by the Russians at the age of less than 39 ), 23\% respondents were at the age of $40-54$, and only $22 \%$ of interviewees crossed the retirement age threshold. In whole, the composition of participants dramatically differed from the average indicators across Russia.

Most of the protesters have higher education that seems to be the outstanding result. That said, $62 \%$ of them had higher education, $13 \%$ were undergraduates (while the rest, or $5 \%$, matched the category of people with the secondary education). In addition, the participants in protest movements have the occupations, which imply a high level of responsibility and motivation for self-realization (features attributed by Florida to the creative class): the vast majority $(46 \%)$ was specialists, students accounted for $12 \%$, managers and business owners stood at $8 \%$. The mix of criteria indicates that the protesters belong to the creative class as interpreted by Florida, albeit with the focus on its specific understanding within Russia, i.e. the most proactive part of the Russian society, from the constructive and spirit-stirring standpoints.

The most serious problem, which the survey was aimed to resolve, was to find out what encouraged all those people to hold a mass-meeting and what provoked street protests. According to the findings, the majority of population has already developed their firm political views with skeptical attitude towards politics in general. Only the issue, which really affects people, is capable of stimulating them to undertake some actions. Undoubtedly, dissatisfaction with the financial state (the reason behind many mass protests in Europe in the course of crisis) is one of the major motives. Protest actions are driven by political motives only when the politics affects economy. E.g., the recent protests in Russia were connected with the changes to pension system, then there were ecological protests, i.e. only those things which directly impact one's life can make present-day human beings change their habits and take part in political fight.

However, the Russian protests were not driven solely by the economic conditions. During the survey, one of the questions was about financial well-being of protesters. It was found that the majority of participants belongs to the middleclass by Russian as well European standards, as $40 \%$ of interviewees replied: "We can buy some expensive things such as a refrigerator or a TV set, but we can't buy a car" (probably, they would need a loan to buy more expensive goods, i.e. these type of goods are nevertheless available for them). Moreover, $28 \%$ of respondents said: "We can buy a car, but we can't say we don't feel pressed for money". $5 \%$ of respondents admitted that they indulge in every pleasure.

This is the fact which threw most of the researchers into dilemma: the participants in street actions were not supposed to be there - they were in a stable financial position, had relatively high social status and prestigious job. All these people are not supposed to take part in protests not because they have something to lose, but because they are supposed to be satisfied with their living standards, consequently, with the political regime, which forms these standards. The answers explaining why people came to the mass-meeting are presented in Figure 3. 
Figure 3: What made you come to the meeting?

\begin{tabular}{|l|c|}
\hline Willingness to show my dissatisfaction with the elections falsification & 73 \\
\hline Accumulated dissatisfaction with the current situation in the country/ government policy & 73 \\
\hline Disappointment by promised modernization policy/ Dmitry Medvedev & 42 \\
\hline $\begin{array}{l}\text { Dissatisfaction with the fact that government doesn't take into consideration opinions of such people like myself/ main } \\
\text { decisions are made without our contribution }\end{array}$ & 52 \\
\hline Solidarity with political parties taking part in the mass-meeting & 15 \\
\hline Good attitude towards mass-meeting organizers & 13 \\
\hline Meetings are interesting to me, it's the current trend & 6 \\
\hline My friends and acquaintances went to this mass-meeting, so I joined them & 10 \\
\hline Other & 3 \\
\hline Difficult to answer & 1 \\
\hline
\end{tabular}

We conclude that the motives which spurred people to join the protests were purely political; moreover, they were related to dissatisfaction with the general situation in Russia, but not with certain political steps, which could worsen their economic or social positions. The primary reason for mass protest outbreaks was supposed falsifications during the presidential elections (the response "Willingness to show my dissatisfaction with the elections falsification" was chosen by $73 \%$ of interviewees). At the same time, the falsification itself, as well as the fact that its absence, would not lead to the different outcome of the elections was not a surprise (the majority of population continue supporting Vladimir Putin). As of August, 2013, about $45 \%$ of the Russians supported Putin, while 15\% of people supported Dmitry Medvedev (the current Prime Minister of Russia). Thus, the support of government can be considered absolute [Trust in Politicians, VCIOM, 2013]. Taking into consideration a high level of protester's personal competency, he or she is well-aware of that fact. It is the general discontent (answer "Accumulated dissatisfaction with the current situation in the country/ government policy"), which provoked the political protests. This was the expanded-in-time reason. The dissatisfaction was latent but then came out to the surface. In order to answer the question why the dissatisfaction has increased so much that it provoked mass protests, we should turn our attention to the answer "dissatisfaction with the fact that government doesn't take into consideration opinions of such people like myself/main decisions are made without our contribution", which was second popular among the respondents.

Such an option in a questionnaire could be a surprise, as long as the purely psychological basis of motivations rarely counts in sociological surveys, given the researchers base on the idea of the political apathy of the majority of population, especially of the creative class. It is here where we should look for the creative class, the subject of our research, as well as for the reasons why its representatives increasingly consider emigration.

In the course of protests, there was a number of statements claiming to take into consideration the public opinion on what is going on in the country. Firstly, it was a claim for legitimate elections; secondly, a claim to generally consider population as a source of power, not as an object of manipulation by mass media or government, and to admit the fact that population also knows how the country should be developed. The clear manipulations during the elections, unwillingness not only to hold fair elections, but at least to pretend that they are held fairly, was the motive which triggered street protests and sparked opposition movement.

Despite the fact that these protests did not have any significant outcomes, the protest moods still exist in Russia in one form or another. The protest moods have obviously retracted: it is impossible to expect that people will participate in mass-meetings over several years, especially when it could lead to adverse consequences for an individual person including criminal proceedings. Only the most active part of the population therefore takes part in protests. However, they continue to shape public opinion, though VCIOM says about the weaker support to protest actions [Protest Actions: a Year Later, VCIOM, 2012]. According to this data, 27\% of respondents support opposition meetings, $10 \%$ admit the opportunity of taking part in them, while just a year ago about $40 \%$ of interviewees supported protests. Today protest activity is concentrated in the Internet - the sole source, which is not controlled and censored by the government or mass-media.

Indirect evidence is that the official Russian media actively support the idea of discrediting protest movement participants. It is not just about some TV programmes, where they are portrayed as American agents or criminals who avoid taxes and strike doubtful deals. Importantly, the allegedly analytical contributions about the creative class appear on the websites of the existing political power advocates and aim to represent the modern intellectuals, who participated in protest actions, as lazy people, who view them as hangouts, have enough time for liberal discussions and going along 
the streets up and down wearing a white ribbon (the symbol of protest movements in Russia, which arose during the parliamentary elections in 2011). In the Russian web space the creative class is called "kreatiff" or "kreakl" (to show its alienation from the ordinary Russians and adherence to Western values), and protests, which led to the creative class as a phenomenon through building its self-awareness, are called "glamorous opposition".

The facts evidence that the government, even if it is not afraid of the uprising of the intellectuals, does not rule out the possibility that they can influence the public opinion. To a certain extent, this can explain the introduced and widely discussed laws, which are questionable in terms of international legislature and have worsened the tainted reputation of Russia. The government switches the public attention to different topics, at the same time creating the image of an enemy of Russia: the western liberal values, which demoralize the Russians and are promoted by foreign countries to destroy Russia's uniqueness. By agreeing with such an interpretation of the hasty introductions of legislative measures, we can understand the context, due to which the creative class, besides other things, is described by the authorities as immoral, while the unscrupulous mass media say that the intellectuals, liberals and homosexuals have close meaning.

Thus, the government is trying to produce a negative image of a protester using all means available. However, given all the features indicated above, it is the protester who has all the characteristics of the emerging creative class in Russia. Meanwhile, the reaction of the creative class itself can be unexpected. We believe the major consequence of the authorities' negative reaction has been a new wave of social apathy that leads not to of protests but to stronger willingness to leave Russia as people are convinced that over the next 12 years nothing will change (supposed two terms of Putin's presidency).

\section{Idea of Emigration among the Creative Class}

Thus, the idea of emigration among the creative class is rising as there is less hope about the positive shifts in Russia. In 2012, the peak of emigration moods was registered. According to Levada-Center [The Outflow of Human Capital, Levada-Center, 2012), about $30 \%$ of respondents considered the emigration, from which 3-4 mln people have already taken steps to prepare it. The social portrait of a potential emigrant, presented by sociologists, proves our conclusions about its belonging to the creative class: we mean people with a high level of education and income. The analysis evidences that the existing political and economic system in Russia does not provide enough opportunities for selfrealization. According to Radyukhin, "highly qualified middle-class professionals, feeling ignored by the country's economy and political system, are emigrating in search of greener pastures (Radyukhin, 2012). Based on the data about the number of people, who immigrated to the EU countries, the majority of them put their ideas into practice.

We can say that the emigration moods have already passed their high in Russia. According to sociologists (VCIOM's survey, 2012), the intention to emigrate was expressed by $11 \%$ of the Russians [To Emigrate from Russia? No More! VCIOM 2012a)].

Figure 4: Would you like to go abroad for permanent living? (close-ended question, only one answer possible)

\begin{tabular}{|l|c|c|c|}
\hline & 1991 & June, 2011 & March, 2012 \\
\hline Rather yes & 16 & 22 & 11 \\
\hline Rather no & 70 & 75 & 88 \\
\hline Difficult to answer & 14 & 3 & 2 \\
\hline
\end{tabular}

Despite the decreased number of people who want to leave Russia, the "quality" of them still remains high: these are mainly young, well-educated people, who have achieved quite high social and financial status in the country. The reason behind their willingness to leave is their dissatisfaction with the opportunities for self-realization in Russia, and, generally speaking, dissatisfaction with social institutes during Putin's rule. Lack of possibility to personally influence the situation in the country and the increasingly intensified authoritative regime leads to the fact that people feel lack of prospects in the country and willingness to leave it.

The reasons, which stop creative class from massive emigration, remained connected with the provision of employment abroad: potential immigrants are competent enough to assess their own prospects in Europe. There is no data about the employment of those who immigrated to Europe, but there is data about the jobs migrants from the other countries obtained in Europe. It is well-known that the majority of immigrants have low-prestigious and low-paid jobs. E.g., Ahmad (Ahmad, 2011) says that more than a half of Pakistanis and Indians who came to Finland have a university degree. However, the majority (53\%) of immigrants, surveyed by Ahmad, work in restaurants and catering, and in general 
" $90 \%$ of all the informants' jobs were concentrated in the low-prestige sectors of the labour market".

Given the main reason for the Russians to leave for the EU remains social and psychological factors, the worst obstacle for emigration is lack of financial capabilities for seeking a job, which would match the level of education and qualification degree, and leads to unavoidable decline in social status. However, pro-emigration sentiments among this part of population demonstrate its distrust towards the Russian regime and are undoubtedly dangerous for the country.

\section{Conclusion}

The analysis shows that the number of the Russians immigrating to Europe is insignificant in absolute terms and compared to Russia's overall scope. However, among the emigrants or those who consider emigration, the majority is representatives of the creative class - young, well-educated professionals with a high social status in Russia. Their social features generally conform to social portrait of participants in the local protest movements, and the rise of emigration moods coincided in time with the outbreak of opposition movements and protest activities. All this suggests emigration moods have been the result of the inadequate governmental reaction to massive protests. Opposition opinion was not taken into consideration, instead, the official reaction was tough actions and repressions. Under such circumstances, not only was there no point, but it was also dangerous for the creative class to continue participating in protest actions, and it has chosen another way: not try to change the current situation in Russia, but just leave the country instead.

At the same time, it is wrong to equal intention to emigrate to emigration itself. Having expressed such intention, people can prepare for emigration over the years and then never actually do it, primarily because of the lack of opportunities to find a good job in Europe (which has become even more difficult due to the European crisis). However, in this case, this intention is just an obvious protest against the current regime.

\section{References}

Ahmad A. (2011) Connecting with work. European Societies, Vol. 13, N. 5, PP. 687-712.

Bell D. (1976) The Coming of Post-Industrial Society: A Venture in Social Forecasting. (1st Printing ed.). Basic Books.

Data on the Monthly Income of Employees by Categories and Professional Groups for October, 2011. [Online] Available: http://www.gks.ru/wps/wcm/connect/rosstat_main/rosstat/ru/statistics/wages/labour_costs/(October 15, 2913)

Drucker P. (1993) The Post-Capitalist Society. New York City: Harper Business.

Dubinin, B. (2009) Small and Feared. Executive.ru. [Online] Available: http://www.e-xecutive.ru/knowledge/announcement/1088840/ (August 7, 2013)

Employment Outlook (2013). The Organisation for Economic Co-operation and Development (OECD). [Online] Available: http://www.oecd.org/employment/emp/oecdemploymentoutlook.htm (August 20, 2013)

Florida R. (2002) The Rise of the Creative Class. And How It's Transforming Work, Leisure and Everyday Life. Basic Books.

Gorshkov M., Golenkova Z., Tikhonova N. (2006) The City Middle Class in Present-day Russia. The Research Report. The Institute of Sociology of the Russian Academy of Sciences. [Online] Available: http://www.isras.ru/files/File/Doklad/Doclad_Gorod_sred_ klass.pdf. (November 21, 2013)

Inglehart R. (2004) Human Beliefs and Values: A Cross-Cultural Sourcebook based on the 1999-2002 values Surveys. (Eds.) Miguel Basanez, Jaime Deiz-Medrano, Loek Halman and Ruud Luijkx. Mexico City: Siglo XXI.

Levada-Center (2011). The Outflow of Human Capital. [Online] Available: http://www.levada.ru/17-11-2011/ottok-chelovecheskogokapitala-bdubin-video. (September 20, 2014)

Levada Center (2011a), Press release, 26.12.2011. [Online] Available: http://www.levada.ru/26-12-2011/opros-na-prospekte-sakharova24-dekabrya. (November 30, 2013)

Okara A. (2009) The Creative Class as the Last Hope. Intellectual Russia. [Online] Available: http://www.intelros.ru/intelros/reiting/ reyting_09/material_sofiy/5027-andrej-okara-kreativnyj-klass-kak-poslednyaya-nadezhda.html. (September 20, 2014)

Oreshkin D. (2011) Why people leave Russia? Novaya Gazeta. N 10. [Online] Available: http://www.ryzkov.ru/index.php?option=com_ content\&view=article\&id=30098\&catid=11:2011-12-26-10-30-14\&ltemid=6. (September 20, 2014)

Radyuhin V. (2012) The Russians are leaving ... Russia. The Hindu. [Online] Available: http://www.thehindu.com/opinion/lead/article 2880044.ece?homepage=true. (Janvier 13, 2014)

Renard T. (2011) EU's Foreign Policy: From a Dialogue About Strategic Partnership To a Real Partnership. International Organizations. Research Journal, 4 (35).

Rosstat (2011). Official statistics. Population. Number of Men and Women. [Online] Available: http://www.gks.ru/wps/wcm/connect/ rosstat_main/rosstat/ru/statistics/population/demography/\#(Janvier 13, 2014)

Rosstat (2012). Nearly a quarter of the Russians have a graduate degree. Rosbalt. [Online] Available: http://www.rosbalt.ru/main/ 2012/12/10/1069611.html (November 21, 2013)

Rosstat. International Migration. [Online] Available: http://www.gks.ru/wps/wcm/connect/rosstat_main/rosstat/ru/statistics/population/ demogra phy/\#(November 21, 2013) 
Rosstat. The Migration by Types of Movements. [Online] Available: http://www.gks.ru/wps/wcm/connect/rosstat_main/rosstat/ru/apps/ 2a306f804a69aea29477dc5f17a443bf. (November 21, 2013)

Russia's Ministry of Economic Development. [Online] Available: http://www.economy.gov.ru/minec/activity/sections/strategicPlanning/ concept/. (Javier 13, 2014).

Schumpeter J. (1934) The Theory of Economic Development: An Inquiry Into Profits, Capital, Credit, Interest, and the Business Cycle. Transaction Publishers.

The Analysis of Migration in Russia (2006). International Bank for Reconstruction and Development. [Online] Available: pages.nes.ru/ sguriev/papers/Migration_rus_.pdf. (November 21, 2013)

Toffler A. (1990) Powershift: Knowledge, Wealth and Violence at the Edge of the 21st Century, Plaza \& Janés.

VCIOM (2008) Press Release N. 967, 30.05.2008. [Online] Available: http://wciom.ru/index.php?id=268\&uid=10199. (November 21, 2013)

VCIOM (2012), Press release. N 2188. [Online] Available: http://wciom.ru/index.php?id=459\&uid=113467. (November 21, 2013)

VCIOM (2013). Trust in Politicians. [Online] Available: http://wciom.ru/confidence-politicians/(November 21, 2013)

Zaslavskaya T. (2000) About Social and Transformational Structure of the Russian Society. The Monitoring of the Public Opinion: Economic and Social Changes, 1 (45), 15-19. 